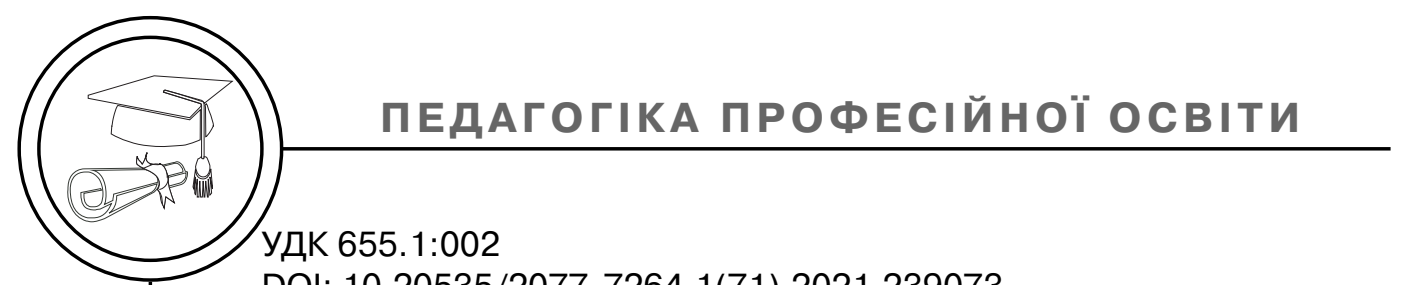

DOI: $10.20535 / 2077-7264.1(71) .2021 .239073$

(ㄱ Т. Ю. Киричок, д-р техн. наук, проф., В. А. Баглай, аспірант, Т. В. Горова, аспірантка, О. П. Сокол, аспірантка, А. О., Комарницька аспірантка, Ю. В. Сичик, аспірант, КПІ ім. Ігоря Сікорського, Київ, Україна

\title{
АНАЛІЗ ВІДПОВІДНОСТІ ФАХОВИХ ВИДАНЬ, ЩО ВХОДЯТЬ ДО НАУКО-МЕТРИЧНИХ БАЗ ДАНИХ, ПРЕДМЕТНІЙ ОБЛАСТІ СПЕЦІАЛЬНОСТІ 186 ВИДАВНИЦТВО ТА ПОЛІГРАФІЯ
}

\begin{abstract}
Проаналізовано фахові видання, що входять до українських та іноземних баз даних з погляду їх відповідності предметній області спеціальності 186 Видавництво та поліграфія. Для аналізу було взято міжнародні науково-метричні бази, такі як Web of Science та Scopus. Визначено перелік наукових видань для публікування досліджень науковців спеціальності 186 Видавництво та поліграфія. Наведено вимоги до опублікування результатів дисертації на здобуття наукових ступенів кандидата наук, доктора наук та доктора філософії.
\end{abstract}

Ключові слова: предметна область спеціальності; міжнародні наукові бази; видавництво та поліграфія; публікації; наукові журнали.

\section{Постановка проблеми}

Сучасна поліграфічна галузь має багато складників з різних галузей науки і техніки. Поліграфічна промисловість - це не тільки книжково-журнальна, паперовобілова, банкнотна продукція, але й продукція, що призначена для використання разом з виробами інших галузей промисловості: паковання та етикетка, наклейки та маркування. Окрім того, засобами поліграфії задруковують не лише папір, картон, пластик, але й тканини, шкіру, скло, метал, дерево та інші основи.
Крім цього значну частку поліграфічної промисловості займає виготовлення мультимедійних електронних видань. I це далеко не повний перелік завдань, що виконуються засобами сучасної поліграфічної техніки, що свідчить про проникнення ії у різні сфери людської діяльності [1].

На сьогоднішній день видавництво та поліграфія увібрали в себе багато складників - не лише безпосередньо додрукарські, друкарські та післядрукарські процеси, але й досягнення інформаційних технологій, математично-

() Автор(и) 2021. Видавець КПІ ім. Ігоря Сікорського.

CC BY 4.0 (https://creativecommons.org/licenses/by/4.0/). 
го моделювання, матеріалознавства, метрології, стандартизації, сертифікації, дизайну тощо.

Така спрямованість та різноманітність сучасного видавництва та поліграфії знайшли своє відображення у розроблених останніми роками стандартах вищої освіти спеціальності 186 Видавництво та поліграфія, де визначено опис предметної області. Так, об'єкти вивчення та діяльності спеціальності є: друковані та електронні видання, паковання, мультимедійні інформаційні продукти та інші види виробів видавництва й поліграфії; процеси оброблення, реєстрації, формування, відтворення, зберігання текстової, графічної, звукової, відео- та іншої мультимедійної інформації; дослідження, удосконалення, створення, виготовлення, поширення виробів видавництва й поліграфії [2]. В затверджених стандартах рівня бакалавра і магістра визначено теоретичний зміст предметної області спеціальності 186: поняття, концепції, принципи опрацювання інформації, розроблення технологічних процесів, проектування та організація виробництва, створення та удосконалення друкованих і електронних видань, паковань, мультимедійних інформаційних продуктів та інших видів виробів видавництва та поліграфії. Крім того, описано методи, засоби та технології спеціальності: методи, засоби та алгоритми розв'язання наукових та прикладних задач, що виникають під час опрацювання інформації, наукових досліджень, розроблення, проектування, організації виробництва, виготовлення, удосконалення, створення інноваційних друкованих і електронних видань, паковань, мультимедійних інформаційних продуктів та інших видів виробів видавництва та поліграфії. Наголошено, що інструментами та обладнанням, що використовується, досліджується, вивчається, удосконалюється в межах спеціальності 186 Видавництво та поліграфія, є: матеріали, апаратно-програмні комплекси, устаткування, методи і засоби інструментального контролю, проектування і моделювання технологічних процесів і видавничополіграфічної продукції; засоби технологічного, інформаційного, інструментального, метрологічного, діагностичного та організаційного забезпечення виробництва [3].

Підготовка докторів філософії спеціальності 186 започаткована 2016 року і наразі ведеться в КПІ ім. Ігоря Сікорського, Українській академії друкарства і Львівській політехніці. Науковий складник підготовки докторів філософії передбачає як виконання власного наукового дослідження, так i публікування його результатів у фахових виданнях України та закордоном.

Вимоги до публікування результатів наукових досліджень постійно оновлюються та удосконалюються. Актуальні вимоги наведено у табл. 1. У зв'язку з цим перед нами постає проблема необхідність визначення переліку журналів, що входять до міжнародних науково-метричних баз, в яких можна публікувати результати наукової діяльності фахівців видавничо-поліграфічного напрямку, зокрема і науковців, які проводять дослідження в рамках роботи над дисертаціями докторів 
наук, кандидатів наук та докторів філософії. Оскільки набуття компетентності «Здатність презентувати результати наукових досліджень та оприлюднювати їх державною, англійською та/або іншою іноземною мовою» $€$ необхідним під час опанування освітнього складника освітньо-наукової програми підготовки докторів філософії в КПІ ім. Ігоря Сікорського, то у межах дисциплін «Методо- логія підготовки рукопису публікації у міжнародний науковий журнал», «Методологія науководослідницької діяльності» студентами третього освітнього рівня протягом кількох років проводився порівняльний аналіз предметної області спеціальності, вимог до публікування результатів наукових досліджень та наявних вітчизняних і закордонних фахових збірників та їх вимог до публікацій.

Таблиця 1

Вимоги до опублікування результатів дисертації на здобуття наукових ступенів кандидата наук, доктора наук та доктора філософії $[4,5]$

\begin{tabular}{|c|c|}
\hline Наукові ступені & Вимоги \\
\hline Кандидат наук & $\begin{array}{l}\text { Три наукові публікації: належать статті у наукових видан- } \\
\text { нях, включених до Переліку фахових видань України (замість } \\
\text { однієї статті може бути зарахована монографія або роз- } \\
\text { діл монографії, опублікованої у співавторстві); } \\
\text { з } 01 \text { вересня } 2020 \text { року необхідна наявність щонайменше } \\
\text { однієї статті у періодичних наукових виданнях інших дер- } \\
\text { жав, які входять до Організації економічного співробітницт- } \\
\text { ва та розвитку та/або Європейського Союзу наукового } \\
\text { напрямку, за яким підготовлено дисертацію здобувача }\end{array}$ \\
\hline Доктор наук & $\begin{array}{l}\text { Необхідна наявність не менше трьох статей з наукового } \\
\text { напрямку, за яким підготовлено дисертацію здобувача, опуб- } \\
\text { лікованих щонайменше у двох різних періодичних видан- } \\
\text { нях, включених до категорії «А» Переліку наукових фахо- } \\
\text { вих видань України, або у закордонних видання, проін- } \\
\text { дексованих у базах даних Web of Science Core Collection } \\
\text { та/або Scopus, а з } 01 \text { вересня } 2022 \text { року - не менше } \\
\text { п'яти таких статей }\end{array}$ \\
\hline $\begin{array}{l}\text { Доктор } \\
\text { філософії }\end{array}$ & $\begin{array}{l}\text { Три наукові публікації: } \\
\text { не менше однієї статті у періодичних наукових виданнях } \\
\text { інших держав, які входять до Організації економічного спів- } \\
\text { робітництва та розвиткута/або Європейського Союзу, з нау- } \\
\text { кового напряму, за яким підготовлено дисертацію здо- } \\
\text { бувача; } \\
\text { статті у наукових виданнях, включених до переліку нау- } \\
\text { кових фахових видань України (замість однієї статті може } \\
\text { бути зараховано монографію або розділ монографії, опуб- } \\
\text { лікованої у співавторстві); } \\
\text { наукова публікація у виданні, віднесеному до першого- } \\
\text { третього квартилів (Q1-Q3) відповідно до класифікації SCImago } \\
\text { Јоurnal аnd Соuntry Rank або Journal Citation Reports, при- } \\
\text { рівнюється до двох публікацій }\end{array}$ \\
\hline
\end{tabular}




\section{Мета роботи}

На основі порівняльного аналізу предметної області спеціальності 186 Видавництво та поліграфія та напрямів українських та закордонних фахових видань визначити перелік наукових видань, в яких науковці видавничополіграфічного напрямку могли б публікувати результати своїх наукових досліджень.

\section{Результати проведених досліджень}

Для вирішення поставленої мети було досліджено міжнародні науково- метричні бази, що існують, станом на 2021 рік. Оскільки загальновизнаними $є$ такі бази даних як Scopus та Web of Science, то в подальших дослідженнях їм приділялась особлива увага.

Для визначення найбільш актуальних баз даних був проведений загальний аналіз всіх існуючих наукометричних баз даних (табл. 2). Розгалужений пошук статей, шляхом аналізу матеріалів співавторів, дав змогу визначити основні журнали, в яких публікуються матеріали видавничо-поліграфічного напрямку. Проаналізувавши приналежність журналів до областей знань, а також розподіл обраних журналів за областями знань, було визначено відповідність цих областей предметній області спеціальності 186 Видавництво та поліграфія.

Приклади статей з кожного журналу, опублікованих авторами провідними вченими спеціальності 186, наведено в табл. 3.

Розподіл обраних журналів за областями знань на основі табл. 3 наведено в табл. 4.

Scopus та Web of Science $€$ найкрупнішими пошуковими система- ми світу, які об'єднують наукові видання в одну базу. Дані системи мають високі вимоги до наукових видань, тому щорічно проводять перевірки журналів на відповідність щодо включення того чи іншого видання у базу Scopus та Web of Science.

Вимоги до опублікування статті y Web of Science $\epsilon$ більш вимогливішими, ніж у Scopus. У Scopus розглядають формальні вимоги до статті, розгляд головного редактора та рецензентів. Повернути статтю на доопрацювання можуть за декількома критеріями, які наведено на рис. 1.

Одне з важливих питань опублікування в журналах Scopus $€$ : з яких причин вам відмовили в публікації? Розглянемо основні критерії, які висвітлені в схемі та детально опишемо причини відмови [52, 53].

1. Стаття не пройшла технічну перевірку. А саме: виникли сумніви щодо плагіату або виявилось, що стаття рецензується в іншому виданні; не повний рукопис статті (може бути відсутня важлива інформація про автора, ключові слова, опис, посилання, таблиці, рисунки, зображення, формули, розрахунки та ін.); написання англійською мовою може бути недостатньо професійним; невідповідність статті вимогам журналу; не повне або нечітке посилання на літературні джерела.

2. Стаття не відповідає науковій тематиці журналу.

3. Не завершене дослідження в статті. Мається на увазі, що в статті може бути розглянуто лише окремі спостереження, що не може вважатися повним дослідженням.

4. Незадовільний аналіз даних дослідження не $є$ достовірним 


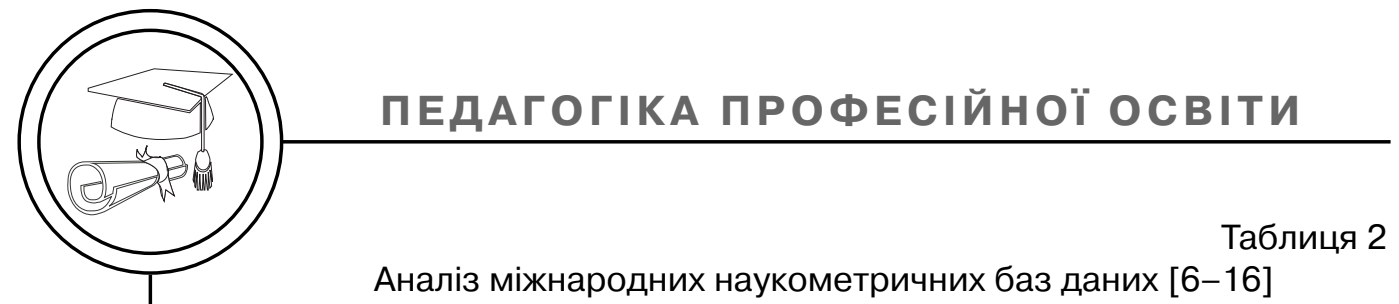

Аналіз міжнародних наукометричних баз даних [6-16]

\begin{tabular}{|c|c|c|c|c|}
\hline Назва & \begin{tabular}{|c|} 
Рік \\
заснування
\end{tabular} & Власник & Рецензування & Галузі знань \\
\hline Scopus & $\begin{array}{c}15 \text { березня } \\
2004 \text { р. }\end{array}$ & $\begin{array}{c}\text { Видавнича } \\
\text { корпорація } \\
\text { Elsevier } \\
\text { (Нідерланди) }\end{array}$ & $\begin{array}{l}22245 \text { академічних жур- } \\
\text { налів (у тому числі } 51 \text { ук- } \\
\text { раїнський) від } 5000 \text { різ- } \\
\text { них видавництв, 58,3 млн } \\
\text { рефератів, більше } 120 \\
\text { тис. книг, 5,5 млн мате-- } \\
\text { ріалів наукових конфе- } \\
\text { ренцій, } 390 \text { галузевих } \\
\text { видань, 25,2 млн па- } \\
\text { тентних записів }\end{array}$ & $\begin{array}{l}\text { Фізичні науки (32 \% - } \\
2012 \text { р., } 41 \% \text { - } 2017 \text { р.) } \\
\text { Медичні науки (31 \% - } \\
2012 \text { р., } 40 \% \text { - } 2017 \text { р.) } \\
\text { Науки про житя (20 \% } \\
\text { - } 2012 \text { р., } 24 \% \text { - } \\
2017 \text { р.) } \\
\text { Соціогуманітарні нау- } \\
\text { ки (17 \% - } 2012 \text { р., } \\
12 \% \text { - } 2017 \text { р.) }\end{array}$ \\
\hline $\begin{array}{c}\text { Web } \\
\text { of science }\end{array}$ & \begin{tabular}{|l|} 
До 2016 р. \\
3 листопа- \\
да 2016 р.
\end{tabular} & $\begin{array}{l}\text { Компанія } \\
\text { Thomson } \\
\text { Reuters } \\
\text { Компанія } \\
\text { Clarivate } \\
\text { Analytics }\end{array}$ & $\begin{array}{l}\text { Понад } 12700 \text { наукових } \\
\text { видань з усього світу, } \\
\text { в тому числі журналів } \\
\text { відкритого доступу, } \\
\text { і більше } 160000 \text { мате- } \\
\text { ріалів конференцій, } \\
\text { понад } 59 \text { млн записів } \\
\text { наукових публікацій, } \\
\text { понад } 1 \text { млрд посилань } \\
\text { пристатейної бібліо- } \\
\text { графії }\end{array}$ & $\begin{array}{l}\text { 43-45 \% - природничі } \\
\text { науки (в т.ч. 15-18 \% - } \\
\text { біологія і медицина, } \\
\text { науки про землю); } \\
30 \text { \% - соціально- } \\
\text { гуманітарні науки; } \\
\text { 25-27 \% - технічні } \\
\text { і прикладні науки }\end{array}$ \\
\hline $\begin{array}{l}\text { Index } \\
\text { Coperni- } \\
\text { cus }\end{array}$ & 1999 p. & Польща & $\begin{array}{l}\text { Містить понад } 30000 \\
\text { журналів, в тому числі } \\
3000 \text { з Польщі }\end{array}$ & - \\
\hline Crossref & 2000 p. & $\begin{array}{l}\text { Міжнарод- } \\
\text { ний фонд } \\
\text { DOI }\end{array}$ & $\begin{array}{l}\text { Більше } 75 \text { млн журналь- } \\
\text { них статей та інших ти- } \\
\text { пів наукових публікацій } \\
\text { (монографій, наборів } \\
\text { даних, дисертацій, тех- } \\
\text { нічних звітів) }\end{array}$ & - \\
\hline WorldCat & 1967 p. & $\begin{array}{l}\text { Заснов- } \\
\text { ник - Fred } \\
\text { Kilgour } \\
\text { Online } \\
\text { Computer } \\
\text { Library } \\
\text { Center }\end{array}$ & $\begin{array}{l}\text { Налічує понад } 240 \text { млн } \\
\text { записів про всі види } \\
\text { творів } 470 \text { мовами } \\
\text { світу (на } 2011 \text { р.) }\end{array}$ & - \\
\hline $\begin{array}{c}\text { CNKI } \\
\text { Scholar }\end{array}$ & 1996 p. & $\begin{array}{l}\text { Tongfang } \\
\text { Knowledge } \\
\text { Network } \\
\text { Technology } \\
\text { Co., Ltd }\end{array}$ & $\begin{array}{l}\text { - China Academic Jour- } \\
\text { nals Full-text Database } \\
\text { (доступно більше } 5000 \\
\text { назв журналів); } \\
\text { - China Doctoral Disser- } \\
\text { tations Full-text Data- } \\
\text { base (доступно більше } \\
\text { 83000 дисертацій); } \\
\text { - China Masters' Theses } \\
\text { Full-text Database (дос- } \\
\text { тупно більше } 1 \text { млн ди- } \\
\text { сертацій) }\end{array}$ & $\begin{array}{l}\text { - Literature/History/ } \\
\text { Philosophy Search } \\
\text { — Politics/Military } \\
\text { Affairs/Law Search } \\
\text { — Education \& Social } \\
\text { Sciences Search } \\
\text { - Electronic Techno- } \\
\text { logy \& Information } \\
\text { Science Search } \\
\text { - Economics \& } \\
\text { Management }\end{array}$ \\
\hline
\end{tabular}


Приклади статей для кожного журналу

Таблиця 3

\begin{tabular}{|c|c|c|}
\hline $\begin{array}{l}\text { Назва бази } \\
\text { даних }\end{array}$ & Назва журналу & Приклади статей \\
\hline \multirow[t]{13}{*}{ Scopus } & $\begin{array}{l}\text { Journal of Graphic } \\
\text { Engineering and } \\
\text { Design }\end{array}$ & $\begin{array}{l}\text { Electronic and microscopic analysis of offset } \\
\text { imprints of barcodes on cardboards / Havenko, } \\
\text { S.\& Konyukhov, O. \& Konyukhova, I. [17] }\end{array}$ \\
\hline & Medziagotyra & $\begin{array}{l}\text { Thermal analysis of braille formed by using } \\
\text { screen printing and inks with thermo powder / } \\
\text { Havenko, S. \& Kochubei, V.\& Labetska, M. \& } \\
\text { Kibirkštis, E. \& Venytè, I. [18] }\end{array}$ \\
\hline & $\begin{array}{l}\text { Proceedings of the } \\
\text { Institution of Mecha- } \\
\text { nical Engineers, Part } \\
\text { J: Journal of Engine- } \\
\text { ering Tribology }\end{array}$ & $\begin{array}{l}\text { Human tactile perception of screen-printed sur- } \\
\text { faces: Self-report and contact mechanics expe- } \\
\text { riments (Conference Paper) / Childs, T. H. C. \& } \\
\text { Henson, B. [19] }\end{array}$ \\
\hline & $\begin{array}{l}\text { Strojniski Vestnik/ } \\
\text { Journal of Mechanical } \\
\text { Engineering }\end{array}$ & $\begin{array}{l}\text { Influence of technological factors on physical } \\
\text { and mechanical properties of laminated prints / } \\
\text { Havenko, S. \& Bogorosh, A.\& Martynyuk, M.\& } \\
\text { Kibirkštis, E. \& Vaitasius, K. [20] }\end{array}$ \\
\hline & $\begin{array}{l}\text { Nordic Pulp and Paper } \\
\text { Research Journal }\end{array}$ & $\begin{array}{l}\text { Nano-lignocellulose from recycled fibres in coa- } \\
\text { tings from aqueous and ethanolic media: Effect } \\
\text { of residual lignin on wetting and offset printing } \\
\text { quality / Imani, M. \& Ghasemian, A. \& } \\
\text { Dehghani-Firouzabadi, M. R. \& Afra, E. \& Gane, } \\
\text { P. A. C. \& Rojas, O. J. [21] }\end{array}$ \\
\hline & $\begin{array}{l}\text { Pulp and Paper } \\
\text { Canada }\end{array}$ & $\begin{array}{l}\text { Printability of PE-coated paperboard with water- } \\
\text { borne flexography: Effects of corona treatment } \\
\text { and surfactants addition (Review) / Mesic, B. \& } \\
\text { Lestelius, M. \& Engström, G. \& Edholm, B. [22] }\end{array}$ \\
\hline & $\begin{array}{l}\text { Measurement Science } \\
\text { and Technology }\end{array}$ & $\begin{array}{l}\text { Dynamic analysis of temporal moisture profiles } \\
\text { in heatset printing studied with near-infrared } \\
\text { spectroscopy / Tåg, C.-M. \& Toiviainen, M. \& } \\
\text { Juuti, M. \& Gane, P. A. C. [23] }\end{array}$ \\
\hline & $\begin{array}{l}\text { Tnternational Journal } \\
\text { of Solids and } \\
\text { Structures }\end{array}$ & $\begin{array}{l}\text { Empirical plasticity models applied for paper } \\
\text { sheets having different anisotropy and dry } \\
\text { solids content levels / Erkkilä, A.-L. \& } \\
\text { Leppänen, T. \& Hämäläinen, J. [24] }\end{array}$ \\
\hline & $\begin{array}{l}\text { Tnternational Journal } \\
\text { of Plasticity }\end{array}$ & $\begin{array}{l}\text { Elasto-plasticity of paper (Conference Paper) / } \\
\text { Castro, J. \& Ostoja-Starzewski, M. [25] }\end{array}$ \\
\hline & Mechanika & $\begin{array}{l}\text { Influence of structure and physical-mechanical } \\
\text { characteristics of threads on the strength of } \\
\text { binding the books / Havenko, S. \& Kibirkštis, E. } \\
\text { \& Gegeckienè, L. \& Khadzhynova, S. \& } \\
\text { Kadyliak, M. [26] }\end{array}$ \\
\hline & $\begin{array}{l}\text { Eastern-European } \\
\text { Journal of Enterprise } \\
\text { Technologies }\end{array}$ & $\begin{array}{l}\text { Determining special features in the topography } \\
\text { of paper with water marks at the micro- and } \\
\text { nanolevels / Kyrychok, T. \& Klymenko, T. \& } \\
\text { Talimonova, N. \& Svezhentsova, K. [27] }\end{array}$ \\
\hline & BioResources & $\begin{array}{l}\text { Banknote paper deterioration factors: Circulation } \\
\text { simulator method / Kyrychok, T. \& Shevchuk, A. } \\
\text { \& Nesterenko, V. \& Kyrychok, P. [28] }\end{array}$ \\
\hline & $\begin{array}{l}\text { Computers and } \\
\text { Education }\end{array}$ & $\begin{array}{l}\text { Reading behavior and the effect of embedded } \\
\text { selfies in role-playing picture e-books: An eye- } \\
\text { tracking investigation / Kao, G. Y.-M. \& Chiang, } \\
\text { X.-Z. \& Foulsham, T. [29] }\end{array}$ \\
\hline
\end{tabular}




\section{ПЕДАГОГІКА ПРОФЕСІЙНОї ОСВІтИ}

Продовження табл. 3

\begin{tabular}{|c|c|c|c|}
\hline & $\begin{array}{c}\text { Назва бази } \\
\text { даних }\end{array}$ & Назва журналу & Приклади статей \\
\hline & \multirow[t]{4}{*}{ Scopus } & $\begin{array}{l}\text { EUREKA, Physics and } \\
\text { Engineering }\end{array}$ & $\begin{array}{l}\text { Development of the optimization model of the } \\
\text { interface of multimedia edition Hrabovskyi, Y. \& } \\
\text { Fedorchenko, V. [30] }\end{array}$ \\
\hline & & $\begin{array}{l}\text { Child Development } \\
\text { Perspectives }\end{array}$ & $\begin{array}{l}\text { Children's Reading With Digital Books: Past } \\
\text { Moving Quickly to the Future / Kucirkova, N. } \\
\text { [31] }\end{array}$ \\
\hline $\bar{T}$ & & $\begin{array}{l}\text { Multimedia Tools and } \\
\text { Applications }\end{array}$ & $\begin{array}{l}\text { ESOTAG: E-book evolution using collaborative } \\
\text { social tagging by readers / Yoo, H.-S. \& Kim, } \\
\text { S.-W.. [32] }\end{array}$ \\
\hline 일 & & $\begin{array}{l}\text { International Journal } \\
\text { of Multimedia and } \\
\text { Ubiquitous } \\
\text { Engineering }\end{array}$ & $\begin{array}{l}\text { Design of user feedback interface for dynamic } \\
\text { updating of E- book content / Choi, J.-R. \& } \\
\text { Hwang, J. \& Lim, S.-B. [33] }\end{array}$ \\
\hline ํ. & \multirow[t]{11}{*}{$\begin{array}{l}\text { Web of } \\
\text { Science }\end{array}$} & $\begin{array}{l}\text { International circular } \\
\text { of graphic education } \\
\text { and research }\end{array}$ & $\begin{array}{l}\text { Sleeve type influence on flexographic print } \\
\text { quality / Petrovic, S. \& Kasikovic, N. [34] }\end{array}$ \\
\hline $\begin{array}{l}0 \\
0 \\
0 \\
0 \\
0\end{array}$ & & Bioresources & $\begin{array}{l}\text { Cellulose Nanofibril Grades' Effect on the } \\
\text { Strength and Drainability of Security Paper / } \\
\text { Kim, K. M. \& Lee, J. Y. \& Jo, H. M. [35] }\end{array}$ \\
\hline$\frac{\sqrt[\sigma]{2}}{\stackrel{\partial}{c}}$ & & $\begin{array}{l}\text { Journal of applied } \\
\text { spectroscopy }\end{array}$ & $\begin{array}{l}\text { Lignin Content in Paper Fibers Assessed Using } \\
\text { IR Reflectance Spectroscopy / Derkacheva, O. } \\
\text { Yu. \& Tsypkin, D. O. [36] }\end{array}$ \\
\hline 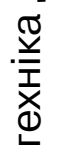 & & $\begin{array}{l}\text { Measurement tech- } \\
\text { niques }\end{array}$ & $\begin{array}{l}\text { Device for measuring print quality characteris- } \\
\text { tics for optically recognizable characters / } \\
\text { Bondarenko, A. V. \& Gudkov, A. V. \& Shendrik, } \\
\text { A. V. [37] }\end{array}$ \\
\hline$\cdot \frac{\pi}{6}$ & & Mechanika & $\begin{array}{l}\text { Investigation of tension of flock printing materi- } \\
\text { als / Mizyuk, O. \& Kibirkstis, E. \& Petraitiene, S. } \\
\text { [38] }\end{array}$ \\
\hline 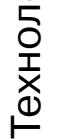 & & $\begin{array}{l}\text { Journal of measure- } \\
\text { ments in engineering }\end{array}$ & $\begin{array}{l}\text { Measurement of longitudinal vibrations of the } \\
\text { rollers in a folding machine / Kibirkstis, E. \& } \\
\text { Miliunas, V. \& Havenko, S. \& Ragulskis, K. \& } \\
\text { Ragulskis, L. [39] }\end{array}$ \\
\hline \multirow{5}{*}{ 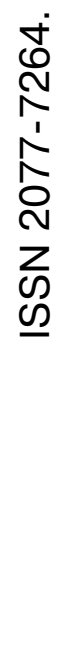 } & & $\begin{array}{l}\text { Nordic pulp \& paper } \\
\text { research journal }\end{array}$ & $\begin{array}{l}\text { Effect of the paper surface properties on the ink } \\
\text { transfer parameters in offset printing / Cigula, T. } \\
\text { \& Tomasegovic, T. \& Hudika, T. [40] }\end{array}$ \\
\hline & & $\begin{array}{l}\text { Journal of vibroengi- } \\
\text { neering }\end{array}$ & $\begin{array}{l}\text { Effect of dynamic regime of rollers of pocket } \\
\text { folding machine to quality of printing products / } \\
\text { Kibirkstis, E. \& Augutis, S. V. \& Vainilavicius, D. } \\
\text { [41] }\end{array}$ \\
\hline & & $\begin{array}{l}\text { Bioresource technolo- } \\
\text { gy }\end{array}$ & $\begin{array}{l}\text { Utilization of calcium carbonate particles from } \\
\text { eggshell waste as coating pigments for ink-jet } \\
\text { printing paper / Yoo, S. \& Hsieh, J. S. \& Zou, P. } \\
\text { [42] }\end{array}$ \\
\hline & & $\begin{array}{l}\text { Composites science } \\
\text { and technology }\end{array}$ & $\begin{array}{l}\text { Determining the fracture resistance of thin } \\
\text { sheet fiber composites - Paper as a model } \\
\text { material / Zechner, J. \& Janko, M. \& Kolednik, } \\
\text { O. [43] }\end{array}$ \\
\hline & & $\begin{array}{l}\text { Packaging technology } \\
\text { and science }\end{array}$ & $\begin{array}{l}\text { Modelling of Migration from Printing Inks on } \\
\text { Paper Packaging / Wang, Z.-W. \& Gao, S. \& Hu, } \\
\text { C.-Y. \& Wu, Y.-M. [44] }\end{array}$ \\
\hline
\end{tabular}


Закінчення табл. 3

\begin{tabular}{|c|c|c|}
\hline $\begin{array}{c}\text { Назва бази } \\
\text { даних }\end{array}$ & Назва журналу & Приклади статей \\
\hline \multirow[t]{7}{*}{$\begin{array}{l}\text { Web of } \\
\text { Science }\end{array}$} & $\begin{array}{l}\text { Mechanics of materi- } \\
\text { als }\end{array}$ & $\begin{array}{l}\text { Basic mechanisms of fluting formation and } \\
\text { retention in paper / Kulachenko, A. \& Gradin, P. } \\
\text { \& Uesaka, T. [45] }\end{array}$ \\
\hline & $\begin{array}{l}\text { Strojniski vestnik-jour-- } \\
\text { nal of mechanical } \\
\text { engineering }\end{array}$ & $\begin{array}{l}\text { Tnfluence of technological factors on physical } \\
\text { and mechanical properties of laminated prints / } \\
\text { Havenko, S. \& Bogorosh, A. \& Martynyuk, M. } \\
\text { [46] }\end{array}$ \\
\hline & $\begin{array}{l}\text { Materials science- } \\
\text { medziagotyra }\end{array}$ & $\begin{array}{l}\text { Tnfluence of Binders on Inkjet Print Quality / } \\
\text { Sousa, S. \& de Sousa, A. M. \& Reis, B. [47] }\end{array}$ \\
\hline & $\begin{array}{l}\text { Journal of early child- } \\
\text { hood literacy }\end{array}$ & $\begin{array}{l}\text { Ten years after: Revisiting the question of e- } \\
\text { book quality as early language and literacy sup- } \\
\text { port / Korat, O. \& Falk, Y. [48] }\end{array}$ \\
\hline & $\begin{array}{l}\text { Journal of chemical } \\
\text { education }\end{array}$ & $\begin{array}{l}\text { Using a Multitouch Book to Enhance the } \\
\text { Student Experience in Organic Chemistry / } \\
\text { Franco, J. \& Provencher, B. A. [49] }\end{array}$ \\
\hline & $\begin{array}{l}\text { Educational sciences- } \\
\text { theory \& practice }\end{array}$ & $\begin{array}{l}\text { Animation Development in Multimedia Teaching } \\
\text { Software Based on Multimedia Tool Book / } \\
\text { Wang, J. \& Wang, L. [50] }\end{array}$ \\
\hline & $\begin{array}{l}\text { Multimedia tools and } \\
\text { applications }\end{array}$ & $\begin{array}{l}\text { ESOTAG: E-book evolution using collaborative } \\
\text { social tagging by readers / Yoo, H.-S. [1] \& Kim, } \\
\text { S.-W. [51] }\end{array}$ \\
\hline
\end{tabular}

або не відповідає нормам, які запроваджені у відповідній сфері, відсутність показників для порівняння, невідповідність дослідження.

5. Недостовірність висновків. А саме: нелогічність, недостовір- ність викладених аргументів, результати роботи не підтверджують висновків, ігнорування частини літератури.

6. Розширений варіант або продовження статті того самого автора. Автор може подрібнити

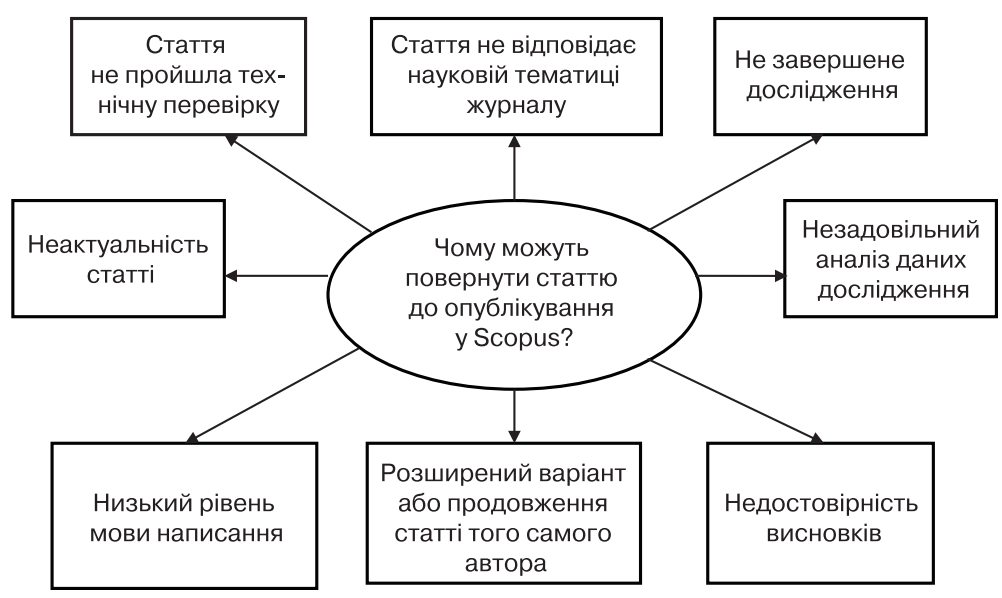

Рис. 1. Критерії повернення статті автору на доопрацювання 
велику статтю з дослідженнями та результатами на частини та представляти як нову публікацію.

7. Низький рівень мови написання. Мова публікації може бути не зрозуміла або мати низький рівень написання, що призводить до відмови у публікації.

8. Неактуальність статті. Стаття може бути не цікава, не мати новизни та наукового інтересу.
Розглянемо які ж вимоги (рис. 2) до опублікування статті в Scopus тa Web of Science $[54,55]$.

1. Оригінальність. За різними джерела оригінальність рукопису має складати 80-95 \%. Треба не забувати, що рукопис буде перевірятися на плагіат.

2. Логічність. Текст має бути побудований продумано, логічно

Таблиця 4

Розподіл журналів за областями знань [14]

\begin{tabular}{|c|c|c|c|c|c|}
\hline \multicolumn{2}{|l|}{ Scopus } & \multicolumn{4}{|c|}{ Web of Science } \\
\hline Область знань & $\begin{array}{l}\text { Кількість } \\
\text { журналів }\end{array}$ & Область знань & $\begin{array}{l}\text { Кількість } \\
\text { журналів }\end{array}$ & Область знань & $\begin{array}{l}\text { Кількість } \\
\text { журналів }\end{array}$ \\
\hline Engineering & 11 & $\begin{array}{l}\text { Engineering } \\
\text { mechanical }\end{array}$ & 3 & Energy fuels & 1 \\
\hline Materials Science & 7 & $\begin{array}{l}\text { Materials science } \\
\text { multidisciplinary }\end{array}$ & 2 & $\begin{array}{l}\text { Engineering ma- } \\
\text { nufacturing }\end{array}$ & 1 \\
\hline $\begin{array}{l}\text { Physics and } \\
\text { Astronomy }\end{array}$ & 5 & Mechanics & 2 & $\begin{array}{l}\text { Food science } \\
\text { technology }\end{array}$ & 1 \\
\hline $\begin{array}{l}\text { Computer } \\
\text { Science }\end{array}$ & 5 & $\begin{array}{l}\text { Materials science } \\
\text { paper wood }\end{array}$ & 2 & $\begin{array}{l}\text { Education educa- } \\
\text { tional research }\end{array}$ & 2 \\
\hline Mathematics & 4 & $\begin{array}{l}\text { Computer sci- } \\
\text { ence information } \\
\text { systems }\end{array}$ & 2 & $\begin{array}{l}\text { Chemistry multi- } \\
\text { disciplinary }\end{array}$ & 1 \\
\hline $\begin{array}{l}\text { Chemical } \\
\text { Engineering }\end{array}$ & 3 & $\begin{array}{l}\text { Materials science } \\
\text { composites }\end{array}$ & 1 & $\begin{array}{l}\text { Education scien- } \\
\text { tific disciplines }\end{array}$ & 1 \\
\hline Social Sciences & 2 & Spectroscopy & 1 & $\begin{array}{l}\text { Imaging science } \\
\text { photographic } \\
\text { technology }\end{array}$ & 1 \\
\hline $\begin{array}{l}\text { Economics, } \\
\text { Econometrics } \\
\text { and Finance }\end{array}$ & 1 & $\begin{array}{l}\text { Engineering mul- } \\
\text { tidisciplinary }\end{array}$ & 1 & $\begin{array}{l}\text { Computer sci- } \\
\text { ence software } \\
\text { engineering }\end{array}$ & 1 \\
\hline $\begin{array}{l}\text { Business, } \\
\text { Management } \\
\text { and Accounting }\end{array}$ & 1 & $\begin{array}{l}\text { Instruments } \\
\text { instrumentation }\end{array}$ & 1 & $\begin{array}{l}\text { Computer sci- } \\
\text { ence theory } \\
\text { methods }\end{array}$ & 1 \\
\hline Energy & 1 & $\begin{array}{l}\text { Engineering bio- } \\
\text { medical }\end{array}$ & 1 & $\begin{array}{l}\text { Engineering elec- } \\
\text { trical electronic }\end{array}$ & 1 \\
\hline $\begin{array}{l}\text { Environmental } \\
\text { Science }\end{array}$ & 1 & $\begin{array}{l}\text { Agricultural engi- } \\
\text { neering }\end{array}$ & 1 & $\begin{array}{l}\text { Information sci- } \\
\text { ence library sci- } \\
\text { ence }\end{array}$ & 1 \\
\hline $\begin{array}{l}\text { Agricultural and } \\
\text { Biological } \\
\text { Sciences }\end{array}$ & 1 & $\begin{array}{l}\text { Biotechnology } \\
\text { applied microbio- } \\
\text { logy }\end{array}$ & 1 & & \\
\hline
\end{tabular}


та крок за кроком висвітлювати свою тематику та дослідження.

3. Написання професійною англійською мовою. Англійська мова є однією з головної вимоги до опублікування. Мова має бути грамотна та професійна.

4. Оформлення статті відповідно до вимог журналу, в якому буде публікація. Необхідно під час оформлення статті до публікації уважно ознайомитися з вимогами (кегль, інтервал, шрифт, відступ, поля сторінки, програма написання формул, нумерація схем, рисунків, таблиця тощо).

5. Чітко виділений заголовок, який не повинен перевищувати більше 10 слів. Заголовок це перше на що звертає увагу не тільки редактор видання, але й читач. Тому заголовок має містити чітке розуміння теми статті для ідентифікації рукопису, яка ідеально підійде до наукової діяльності журналу. Найкраще читаються та цитуються статті із заголовком до 10 слів.
6. Інформація про автора. У даному пункті необхідно правильно вказати автора, місце роботи та всю необхідну інформацію, яку вимагає журнал.

7. Розгорнута анотація. Має містити найважливіші результати дослідження та коротко описати статтю для розуміння того, чи варто читати (купувати) статтю. Адже у більшості наукових журналів представлено тільки анотації, читання повного варіанту статті є платним.

8. Ключові слова. Під ключовими словами розуміють головні категорії та поняття, які необхідні для опису вивчаємого питання, а також для легкого пошуку на веб-ресурсах статей зі схожою тематикою.

9. Вступ, матеріали та методи, результати, опис, висновки. Без даних розділів стаття не буде розглядатися. У вступі необхідно описати мотивацію, цілі, сфери застосування, підтвердити актуальність та описати свою

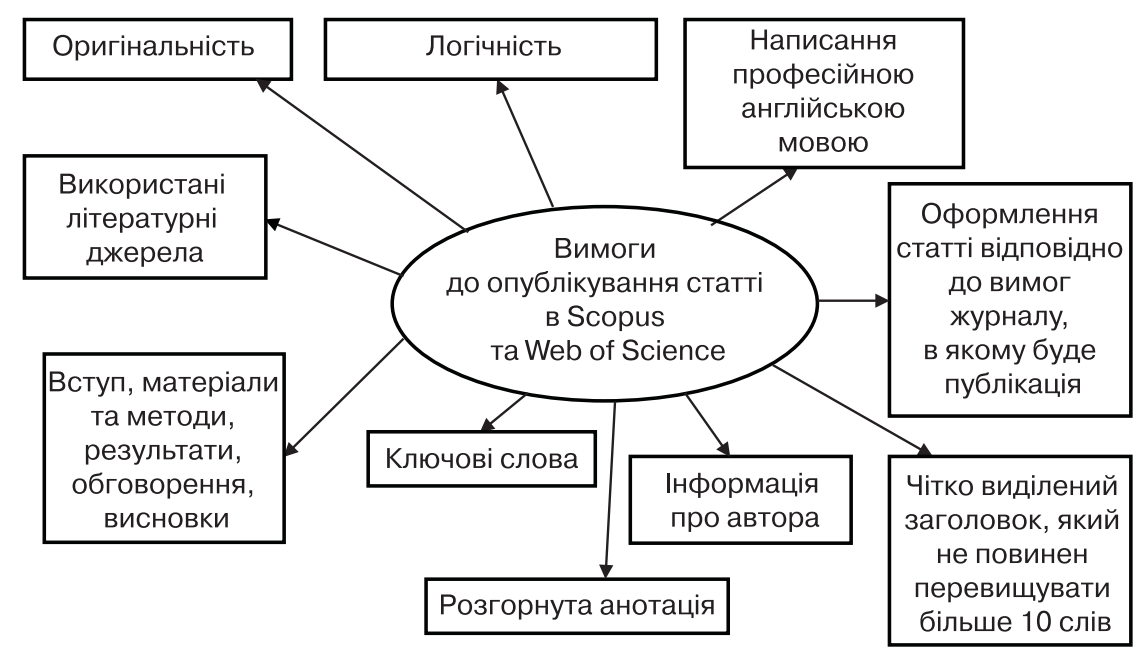

Рис. 2. Вимоги до опублікування статті в базах Scopus та Web of Science 
позицію. У пункті матеріали та методи необхідно описати максимально повну інформацію щодо проведених досліджень. У результатах треба чітко та послідовно викласти огляд результатів. А в обговоренні показати, з якими методиками автор погоджується, а з якими - ні; підтвердити свої думки висновками, порівняннями, доведенням; підкреслити проблеми та перспективи, порівняти різні метод, результати дослідження з аналогічними дослідженнями. Висновки мають бути коротко систематизовано описати всі основні частини статті.

10. Використані літературні джерела. Рекомендовано не менше 20 джерел. Близько 50 \% іноземні джерела, рецензовані в Scopus та WoS - не менше $30 \%$, а також вказувати 2-3 наукові роботи за останні 5-10 років.

Як видно з табл. 4, більшість журналів належать до напрямів Engineering, Materials Science, Computer Science в базі Scopus та до напрямів Engineering mechanical, Materials science multidisciplinary, Mechanics та Computer science information systems в базі Web of Science. Всі ці області знань відповідають окремим складникам предметної області спеціальності 186.

Також доцільно розглянути перелік наукових фахових видань України, де можуть публікуватися фахівці із галузі поліграфії (табл. 5).

Журнали категорії A - це журнали, які відносяться до науково-метричних баз, таких як WoS i Scopus. Ці журнали є найбільш престижними та авторитетними. Фахівці поліграфічної галузі можуть публікувати свої доробки у «Східно-Європейському журналі передових технологій», оскільки тільки він відноситься до категорії «A» [61].

Журнал «Східно-Європейський журнал передових технологій» індексується в світових наукометричних базах даних і системах: Scopus, EBSCO, Directory of Open Access Journals (DOAJ), OpenAIRE, Bielefeld Academic Search Engine (BASE), Index Copernicus Journals Master List, Наукова періодика України - проєкт Національної бібліотеки України імені В. І. Вернадського (НБУВ), WorldCat, CrossRef, CNKI Scholar, MIAR, Polska Bibliografia Naukowa (PBN), Google Академія, Directory of Open Access scholarly Resources (ROAD), Chemical Abstracts Plus (CAplus).

Рубрики журналу: Виробничотехнологічні системи, інформаційні технології, системи управління в промисловості, процеси управління, математика і кібернетика, прикладна фізика, технології органічних і неорганічних речовин, прикладна механіка, енергоощадні технології та обладнання, інформаційно-керуючі системи, екологія, технології та обладнання харчових виробництв, матеріалознавство [56].

Журнали «Квалілогія книги», «Наукові записки», «Поліграфія і видавнича справа», «Технологія і техніка друкарства» відносяться до категорії «Б». Категорія «Б» це наукові видання, які включені до інших міжнародних наукометричних баз даних (статті підлягають незалежному рецензуванню; у редколегії наявні іноземні фахівці з відповідної галузі науки (знань); статті мають цифровий ідентифікатор DOI; анотації до статей англійською мовою містять не менш як 1800 знаків) [61]. 
Тематичною спрямованістю «Квалілогії книги» $€-$ системний аналіз технологічних процесів у поліграфії, технологія електронних видань, технологія устаткування поліграфічного виробництва, поліграфічні матеріали, сучасні технології оздоблення друкованої продукції [57].

Тематичною спрямованістю «Наукових записок» $\epsilon-$ розгляд проблем поліграфічного машино-

Таблиця 5

Перелік фахових видань України з поліграфії [56-60]

\begin{tabular}{|c|c|c|c|c|}
\hline № & Назва видання & $\begin{array}{c}\text { Засновник } \\
\text { (співзасновник) }\end{array}$ & $\begin{array}{c}\text { Галузь науки, код (шифр) } \\
\text { спеціальності або галузь } \\
\text { знань }\end{array}$ & $\begin{array}{l}\text { Категорія } \\
\text { журналу }\end{array}$ \\
\hline 1 & $\begin{array}{l}\text { Східно- } \\
\text { Європейський } \\
\text { журнал передових } \\
\text { технологій }\end{array}$ & $\begin{array}{l}\text { Український } \\
\text { державний } \\
\text { університет } \\
\text { залізничного } \\
\text { транспорту, } \\
\text { ПП «Технологічний } \\
\text { центр» }\end{array}$ & $\begin{array}{l}\text { технічні спеціальності- } \\
131,132,133 \\
\text { технічні, фізико-мате- } \\
\text { матичні спеціальності - } \\
\text { 101, } 113,121,122,123, \\
125,126,151,152,161, \\
163,181,182,261,273, \\
274,275 \\
\text { технічні спеціальності - } \\
124,134,135,136,141, \\
142,143,144,145,171, \\
172,183,184,185,186, \\
271,272 \\
\text { фізико-математичні } \\
\text { спеціальності - } 104, \\
105\end{array}$ & $\bar{A}$ \\
\hline 2 & Квалілогія книги & $\begin{array}{l}\text { Українська } \\
\text { академія } \\
\text { друкарства }\end{array}$ & $\begin{array}{l}\text { Технічні спеціальності - } \\
126,131,133,186\end{array}$ & 5 \\
\hline 3 & Наукові записки & $\begin{array}{l}\text { Українська } \\
\text { академія } \\
\text { друкарства }\end{array}$ & $\begin{array}{l}\text { Технічні спеціальності- } \\
122,126,131,133,151, \\
186 \\
\text { Економічні спеціально- } \\
\text { сті - } 051,073\end{array}$ & 6 \\
\hline 4 & $\begin{array}{l}\text { Поліграфія і } \\
\text { видавнича справа }\end{array}$ & $\begin{array}{l}\text { Українська } \\
\text { академія } \\
\text { друкарства }\end{array}$ & $\begin{array}{l}\text { Технічні спеціальності - } \\
126,131,133,151,186 \\
\text { соціальні спеціально- } \\
\text { сті - } 061\end{array}$ & 5 \\
\hline 5 & $\begin{array}{l}\text { Технологія і техніка } \\
\text { друкарства }\end{array}$ & \begin{tabular}{l|} 
Національний \\
технічний \\
університет України \\
«Київський \\
політехнічний \\
інститут імені Ігоря \\
Сікорського»
\end{tabular} & $\begin{array}{l}\text { філологічні спеціально- } \\
\text { сті - } 061 \\
\text { технічні спеціальності - } \\
186\end{array}$ & 5 \\
\hline
\end{tabular}


будування, технології поліграфічного виробництва і поліграфічних матеріалів, інформаційних технологій і автоматизації поліграфічного виробництва, розвитку економіки та соціальних комунікацій у видавничо-поліграфічному комплексі [58].

Тематичною спрямованістю «Поліграфії і видавничої справи» $\epsilon-$ висвітлення актуальних питань поліграфічного машинобудування, матеріалознавства та технології поліграфічного виробництва, видавничої справи, соціальних комунікацій та книгорозповсюдження [59].

Тематичною спрямованістю «Технології та техніки друкарства» $\epsilon-$ висвітлення теоретичних і практичних досягнень вітчизняної та зарубіжної науки в галузі методів та засобів друку; розгляд проблем та перспектив розвитку технології, матеріалів та техніки видавничої справи, поліграфії та поширення видань; удосконалення і розробка нової техніки та технологічних процесів поліграфічного виробництва; розробка та дослідження витратних матеріалів друкарства; економічна стратегія галузі, маркетинг та менеджмент у видавничо-поліграфічній справі; стандартизація; філологічні аспекти видавничої справи і поліграфічного виробництва; наукові досягнення, експериментальні результати, математичні моделі у видавничо-поліграфічній справі та інших галузях економіки, машинобудування, хімічних технологій [59].

\section{Висновки}

Проведено аналіз існуючих міжнародних наукометричних баз та визначено перелік популярних журналів, що входять до цих баз, де можуть публікувати результати наукової діяльності фахівці видавничо-поліграфічного напряму. Аналітичний огляд показав, що відповідними до предметної області спеціальності 186 Видавництво та поліграфія, окрім українських фахових збірників, $є$ зарубіжні видання з різних областей знань. До найпопулярніших українських збірників можна віднести: «Східно-Європейський журнал передових технологій», «Квалілогія книги», «Технологія і техніка друкарства» тощо. Що ж стосується іноземних видань, то фахівці видавничо-поліграфічного напряму можуть публікувати свої результати наукової діяльності у таких журналах: «Journal of Graphic Engineering and Design», «Nordic Pulp and Paper Research Journal», «Pulp and Paper Canada», «Packaging technology and science», «Multimedia Tools and Applications» та багато інших.

Також було визначено критерії успішного публікування та вимоги до опублікування результатів наукової діяльності, такі як оригінальність та логічність статті, написання професійною англійською мовою, відповідність оформлення статті, помірний заголовок, інформація про автора, розгорнута анотація, наявність вступу, матеріалів та методів, результатів, обговорення, висновків, список використаних джерел.

\section{Список використаної літератури}

1. Сучасна поліграфія. Можливості. [Електронний ресурс]. Режим доступу: https://vizytka.ua/blog/suchasna-polihrafiya-mozhlyvosti. 
2. Наказ від 04.03.2020 р. № 373 «Про затвердження стандарту вищої освіти за спеціальності 186 «Видавництво та поліграфія» для першого (бакалаврського) рівня вищої освіти. [Електронний ресурс]. Режим доступу: https://mon.gov.ua/storage/app/media/vishcha-osvita/zatverdzeni\%20standarty/2020/03/186-vidavnitctvo-B.pdf.

3. Відомості про самооцінювання освітньої програми. [Електронний ресурс]. Режим доступу: https://mon.gov.ua/storage/app/media/vishcha-osvita/zatverdzeni\%20standarty/2020/03/186-vidavnitctvo-B.pdf.

4. Постанова Кабінету Міністрів України від 06.03.2019 р. № 167 «Про проведення експерименту з присудження ступеня доктора філософії». [Електронний ресурс]. Режим доступу: https://rada.kpi.ua/node/1020.

5. Постанова Кабінету Міністрів України від 21.10.2020 р. № 979 «Про внесення змін до постанов Кабінету Міністрів України від 27.07.2016 р. № 567 і від 06.03.2019 р. № 167». [Електронний ресурс]. Режим доступу: https://www.kmu.gov.ua/npas/pro-vnesennya-zmin-do-postanov-kabinetuministriv-ukrayini-vid-27-lipnya-2016-r-567-i-vid-6-bereznya-2019-r-167i211020-979.

6. Офіційний сайт «Наукова бібліотека ДЗ «Дніпровська медична академія МОЗ України». Міжнародні наукометричні бази даних. [Електронний pecypc]. Режим доступу: http://library.dsma.dp.ua/images/Naukovcam/ Mijnarnaukbazdan.pdf, вільний. Назва з екрану. Мова укр.

7. Офіційний сайт «Національна бібліотека України імені В. І. Вернадського». Міжнародні наукометричні бази. [Електронний ресурс]. Режим доступу: http://www.nbuv.gov.ua/node/1367.

8. Офіційний сайт «Східноєвропейський національний університет імені Лесі Українки». Міжнародні наукометричні бази. [Електронний ресурс]. Режим доступу: https://eenu.edu.ua/uk/mizhnarodni-naukometrichni-bazi, вільний. Назва з екрану. Мова укр.

9. Офіційний сайт «Національна бібліотека України імені В. І. Вернадського». Наукометричні бази даних. [Електронний ресурс]. Режим доступу: http://www.nbuv.gov.ua/node/1367, вільний. Назва з екрану. Мова укр.

10. Офіційний сайт «Вікіпедія. Вільна енциклопедія». Scopus. [Електронний ресурс]. Режим доступу: https://uk.wikipedia.org/wiki/Scopus, вільний. Назва з екрану. Мова укр.

11. Офіційний сайт «Публикация научных статей». Публикация в Web of Science. [Електронний ресурс]. Режим доступу: https://wos-scopus.com/ publikacija-v-web-of-science/, вільний. Назва з екрану. Мова poc.

12. Офіційний сайт «Вікіпедія. Вільна енциклопедія». Web of Science. [Електронний ресурс]. Режим доступу: https://uk.wikipedia.org/wiki/ Web of Science, вільний. Назва з екрану. Мова укр.

13. Офіційний сайт «Вікіпедія. Вільна енциклопедія». Google Schoolar. [Електронний ресурс]. Режим доступу: https://uk.wikipedia.org/wiki/ Google Scholar, вільний. Назва з екрану. Мова укр.

14. Офіційний сайт «Научная библиотека Черниговского национального технологического университета». Наукометрические базы данных. [Електронний ресурс]. Режим доступу: http://library2.stu.cn.ua/ru/ru/ v_pomoschj_uchenomu/naukometricheskie_bazi_dannih/, вільний. Назва 3 екрану. Мова рос. 
15. Офіційний сайт «Вікіпедія. Вільна енциклопедія». IndexCopernicus. [Електронний ресурс]. Режим доступу: https://uk.wikipedia.org/wiki/ Index_Copernicus, вільний. Назва з екрану. Мова укр.

16. Офіційний сайт «Вікіпедія. Вільна енциклопедія». CrossRef. [Електронний ресурс]. Режим доступу: https://uk.wikipedia.org/wiki/CrossRef, вільний. Назва з екрану. Мова укр.

17. Havenko S. Electronic and microscopic analysis of offset imprints of barcodes on cardboards / S. Havenko, O. Konyukhov, I. Konyukhova // Journal of Graphic Engineering and Design. 2019. Volume 10. Issue 1. pp. 19-24.

18. Havenko $S$. Thermal analysis of braille formed by using screen printing and inks with thermo powder / S. Havenko, V. Kochubei, M. Labetska, E. Kibirkštis, I. Venytè // Medziagotyra. 2015. Volume 21. Issue 1. pp. 52-56. DOI 10.5755/j01.ms.21.1.5702.

19. Childs T.H.C. Human tactile perception of screen-printed surfaces: Selfreport and contact mechanics experiments / T.H.C. Childs, B. Henson // Proceedings of the Institution of Mechanical Engineers, Part J: Journal of Engineering Tribology. 2007. Volume 221. Issue 3. pp. 427-441. DOI 10.1243/13506501JET217.

20. Havenko S. Influence of technological factors on physical and mechanical properties of laminated prints / S. Havenko, A. Bogorosh, M. Martynyuk, E. Kibirkštis, K. Vaitasius // Strojniski Vestnik. Journal of Mechanical Engineering. 2008. Volume 54. Issue 3. pp. 225-231.

21. Imani M. Nano-lignocellulose from recycled fibres in coatings from aqueous and ethanolic media: Effect of residual lignin on wetting and offset printing quality / M. Imani, A. Ghasemian, M. R. Dehghani-Firouzabadi, E. Afra, P.A.C. Gane, O. J. Rojas // Nordic Pulp and Paper Research Journal. 2019. Volume 34. Issue 2. pp. 200-210.

22. Mesic B. Printability of PE-coated paperboard with water-borne flexography: Effects of corona treatment and surfactants addition / B. Mesic, M. Lestelius, G. Engström, B. Edholm // Pulp and Paper Canada. 2005. Volume 106. Issue 11. pp. 36-41.

23. Tåg C.-M. Dynamic analysis of temporal moisture profiles in heatset printing studied with near-infrared spectroscopy / C.-M. Tåg, M. Toiviainen, M. Juuti, P.A.C. Gane // Measurement Science and Technology. 2010. Volume 21. Issue 10. DOI 10.1088/0957-0233/21/10/105602.

24. Erkkilä A.-L. Empirical plasticity models applied for paper sheets having different anisotropy and dry solids content levels / A.-L. Erkkilä, T. Leppänen, J. Hämäläinen // International Journal of Solids and Structures. 2013. Volume 50. Issue 14-15. pp. 2151-2179. DOI 10.1016/j.ijsolstr.2013.03.004.

25. Castro J. Elasto-plasticity of paper / J. Castro, M. Ostoja-Starzewski // International Journal of Plasticity. 2003. Volume 19. Issue 12. pp. 2083-2098.

26. Havenko S. Influence of structure and physical-mechanical characteristics of threads on the strength of binding the books / S. Havenko, E. Kibirkštis, L. Gegeckienè, S. Khadzhynova, M. Kadyliak // Mechanika. 2019. Volume 25. Issue 4. pp. 313-319. DOI 10.5755/j01.mech.25.4.22774.

27. Kyrychok T. Determining special features in the topography of paper with water marks at the micro- and nanolevels / T. Kyrychok, T. Klymenko, N. Talimonova, K. Svezhentsova // Eastern-European Journal of Enterprise Technologies. 2019. Volume 2. Issue 12-98. pp. 28-35. DOI 10.15587/1729-4061.2019.164071. 
28. Kyrychok T. Banknote paper deterioration factors: Circulation simulator method / T. Kyrychok, A. Shevchuk, V. Nesterenko, P. Kyrychok // BioResources. 2014. Volume 9. Issue 1. pp. 710-724.

29. Kao G. Y. Reading behavior and the effect of embedded selfies in roleplaying picture e-books: An eye-tracking investigation / G. Y. Kao, X.-Z. Chiang, T. Foulsham // Computers and Education. 2019. Volume 136. pp. 99-112. DOI 10.1016/j.compedu.2019.03.010.

30. Hrabovskyi Y. Development of the optimization model of the interface of multimedia edition / Y. Hrabovskyi, V. Fedorchenko // EUREKA, Physics and Engineering. 2019. Режим доступу: https://doi.org/10.21303/2461$\underline{4262.2019 .00902 .}$.

31. Kucirkova N. Children's Reading With Digital Books: Past Moving Quickly to the Future / N. Kucirkova // Child Development Perspectives, 2019. Volume 13. Issue 4. pp. 208-214. DOI10.1111/cdep.12339.

32. Yoo H.-S. ESOTAG: E-book evolution using collaborative social tagging by readers / H.-S. Yoo, S.-W. Kim // Multimedia Tools and Applications. 2016. Volume 75. Issue 20. pp. 12795-12813. DOI10.1007/s11042-016-3404-4.

33. Choi J.-R. Design of User Feedback Interface for Dynamic Updating of E-Book Content / J.-R. Choi, J. Hwang, S.-B. Lim // International Journal of Multimedia and Ubiquitous Engineering. 2015. Vol. 10. No. 11. pp. 359-368.

34. Petrovic S. Sleeve type influence on flexographic print quality / S. Petrovic, N. Kasikovic. [Електронний ресурс]. Режим доступу: https://www.webofscience.com/wos/woscc/full-record/WOS:000460950700006.

35. Kim K. M. Cellulose Nanofibril Grades' Effect on the Strength and Drainability of Security Paper / K. M. Kim, J. Y. Lee, H. M. Jo. [Електронний ресурс]. Режим доступу: https://www.webofscience.com/wos/woscc/full-record/wOS: 000493997400056.

36. Derkacheva O. Yu. Lignin Content in Paper Fibers Assessed Using IR Reflectance Spectroscopy / O. Yu. Derkacheva, D. O. Tsypkin. [Електронний ресурс]. Режим доступу: https://www.webofscience.com/wos/woscc/fullrecord/WOS:000423710700022.

37. Bondarenko A. V. Device for measuring print quality characteristics for optically recognizable characters / A. V. Bondarenko, A. V. Gudkov, A. V. Shendrik. [Електронний ресурс]. Режим доступу: https://www.webofscience.com/wos/ woscc/full-record/WOS:000258192400011.

38. Mizyuk O. Investigation of tension of flock printing materials / O. Mizyuk, E. Kibirkstis, S. Petraitiene. [Електронний ресурс]. Режим доступу: https:// mechanika.ktu.It/index.php/Mech/article/view/12159.

39. Kibirkstis E. Measurement of longitudinal vibrations of the rollers in a folding machine / Kibirkstis E., V. Miliunas, S. Havenko, K. Ragulskis, L. Ragulskis. [Електронний ресурс]. Режим доступу: https://www.jvejournals.com/article/18375.

40. Cigula T. Effect of the paper surface properties on the ink transfer parameters in offset printing / T. Cigula, T. Tomasegovic, T. Hudika. [Електронний ресурс]. Режим доступу: https://www.webofscience.com/wos/woscc/fullrecord/WOS:000497995600015.

41. Kibirkstis E. Effect of dynamic regime of rollers of pocket folding machine to quality of printing products / E. Kibirkstis, S. V. Augutis, D. Vainilavicius. [Електронний ресурс]. Режим доступу: https://www.webofscience.com/wos/ woscc/full-record/WOS:000362551100011. 
42. Yoo S. Utilization of calcium carbonate particles from eggshell waste as coating pigments for ink-jet printing paper / S. Yoo, J. S. Hsieh, Р. Zou. [Електронний ресурс]. Режим доступу: https://www.webofscience.com/wos/ woscc/full-record/WOS:000270147700039.

43. Zechner J. Determining the fracture resistance of thin sheet fiber composites - Paper as a model material / J. Zechner, M. Janko, O. Kolednik. [Електронний ресурс]. Режим доступу: https://www.researchgate.net/publication/257100518_Determining_the_fracture_resistance_of_thin_sheet_fiber_co mposites_- Paper_as_a model_material.

44. Wang Z.-W. Modelling of Migration from Printing Inks on Paper Packaging / Z.-W. Wang, S. Gao, C.-Y. Hu, Y.-M. Wu. [Електронний ресурс]. Режим доступу: https://www.semanticscholar.org/paper/Modelling-of-Migration-fromPrinting-Inks-on-Paper-Wang-Gao/b7d268e59335dd313d69b44e6f17b98d7f657d40.

45. Kulachenko A. Basic mechanisms of fluting formation and retention in paper / A. Kulachenko, P. Gradin, T. Uesaka. [Електронний ресурс]. Режим доступу: https://www.diva-portal.org/smash/get/diva2:227104/FULLTEXT01. pdfFibre.

46. Havenko S. Influence of technological factors on physical and mechanical properties of laminated prints / S. Havenko, A. Bogorosh, M. Martynyuk. [Електронний ресурс]. Режим доступу: https://www.webofscience.com/wos/ woscc/full-record/WOS:000256504600008.

47. Sousa S. Influence of Binders on Inkjet Print Quality / S. Sousa, A. M. de Sousa, B. Reis. [Електронний ресурс]. Режим доступу: https://www.webofscience. com/wos/woscc/full-record/WOS:000334672000010.

48. Korat $\mathrm{O}$. Ten years after: Revisiting the question of e-book quality as early language and literacy support / O. Korat, Y. Falk. [Електронний ресурс]. Режим доступу: https://journals.sagepub.com/doi/abs/10.1177/1468798417712105.

49. Franco J. Using a Multitouch Book to Enhance the Student Experience in Organic Chemistry / J. Franco, B. A. Provencher. [Електронний ресурс]. Peжим доступу: https://dialnet.unirioja.es/servlet/articulo?codigo=6846738.

50. Wang J. Animation Development in Multimedia Teaching Software Based on Multimedia Tool Book / J. Wang, L. Wang. [Електронний ресурс]. Режим доступу: https://jestp.com/index.php/estp/article/view/252.

51. Yoo H.-S. ESOTAG: E-book evolution using collaborative social tagging by readers / H.-S. Yoo, S.-W. Kim. [Електронний ресурс]. Режим доступу: https://www.semanticscholar.org /paper/ESOTAG\%3A-E-book-evolutionusing-collaborative-social-Yoo-Kim/888c21d415f27837fbbec174d30e7517f441a2a3.

52. Основні вимоги до статей, що публікують в журналах, які індексуються в Scopus. [Електронний ресурс]. Режим доступу: http://ua.publ.science/

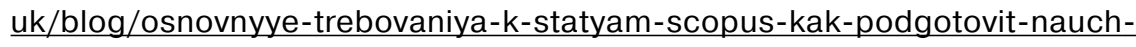
nuyu-rabotu-kotoraya-proydet-retsenzirovaniye.

53. Як опублікувати наукову статтю в Scopus. [Електронний ресурс]. Режим доступу: http://osvita.ua/vnz/69911/\#: :text=\%D0\%92\%D1\%96\% D0\%B4\%D1\%85\%D0\%B8\%D0\%BB\%D0\%B8\%D1\%82\%D0\%B8\%20\%D1\%8 1\%D1\%82\%D0\%B0\%D1\%82\%D1\%82\%D1\%8E\%20\%D0\%B7\%D0\%B0\%20\% D1\%86\%D0\%B8\%D0\%BC\%20\%D0\%BA\%D1\%80\%D0\%B8\%D1\%82\%D0\%B 5\%D1\%80\%D1\%96\%D1\%94\%D0\%BC,\%2C\%20\%D0\%BA\%D0\%BB\%D1\%8E \%D1\%87\%D0\%BE\%D0\%B2\%D1\%96\%20\%D1\%81\%D0\%BB\%D0\%BE\%D0\% 
B2\%D0\%B0\%2C\%20\%D0\%BE\%D1\%81\%D0\%BD\%D0\%BE\%D0\%B2\%D0\%B D\%D0\%B8\%D0\%B9\%20\%D1\%82\%D0\%B5\%D0\%BA\%D1\%81\%D1\%82\%2C.

54. 35 порад, які допоможуть підготувати статтю для публікації в журналах, що індексуються в Scopus та Web of Science. [Електронний ресурс]. Режим доступу: https://nim.media/articles/35-porad-yaki-dopomozhut-pidgotuvati-stattyu-dlya-publikatsiyi-v-zhurnalakh-shcho-indeksuyutsya-v-scopus-ta-web-of-science.

55. Как опубликовать статью в Scopus? [Електронний ресурс]. Режим доступу: https://openscience.in.ua/scopus-article.html.

56. Офіційний сайт «Східно-Європейський журнал передових технологій». Наша історія. [Електронний ресурс]. Режим доступу: http://jet.com.ua/uk/, вільний. Назва з екрану. Мова укр.

57. Офіційний сайт «Квалілогія книги». Квалілогія книги. [Електронний pecypc]. Режим доступу: https://www.uad.lviv.ua/kvalilohiia-knyhy, вільний. Назва з екрану. Мова укр.

58. Офіційний сайт «Наукові записки». Наукові записки. [Електронний pecypc]. Режим доступу: http://www.uad.lviv.ua/naukovi-zapiski, вільний. Назва з екрану. Мова укр.

59. Офіційний сайт «Поліграфія і видавнича справа». Поліграфія і видавнича справа. [Електронний ресурс]. Режим доступу: https://www.uad.lviv. ua/polihrafiia-i-vydavnycha-sprava, вільний. Назва з екрану. Мова укр.

60. Офіційний сайт «Технологія і техніка друкарства». Про журнал. [Електронний ресурс]. Режим доступу: http://ttdruk.vpi.kpi.ua/, вільний. Назва 3 екрану. Мова укр.

61. Офіційний сайт «ПАН БІБЛІОТЕКАР». Категорії А, Б, В для наукових фахових видань України. [Електронний ресурс]. Режим доступу: https:// www.xn-80abaqzevto0rc.xn_j1amh/2017/05/blog-post_17.html, вільний. Назва з екрану. Мова укр.

\section{References}

1. Suchasna polihrafiia. Mozhlyvosti. [Modern printing. Opportunities]. Retrieved from https://vizytka.ua/blog/suchasna-polihrafiya-mozhlyvosti [in Ukrainian].

2. Nakaz vid 04.03.2020 r. № 373 'Pro zatverdzhennia standartu vyshchoi osvity za spetsialnosti 186 'Vydavnytstvo ta polihrafiia' dlia pershoho (bakalavrskoho) rivnia vyshchoi osvity'. [Order of 04.03.2020 № 373 'On approval of the standard of higher education in the specialty 186 'Publishing and Printing' for the first (bachelor's) level of higher education]. Retrieved from https://mon. gov.ua/storage/app/media/vishcha-osvita/zatverdzeni\%20standarty/2020/03/186-vidavnitctvo-B.pdf [in Ukrainian].

3. Vidomosti pro samootsiniuvannia osvitnoi prohramy. [Information on selfassessment of the educational program]. Retrieved from https://mon.gov.ua/ storage/app/media/vishcha-osvita/zatverdzeni\%20standarty/2020/03/186vidavnitctvo-B.pdf [in Ukrainian].

4. Postanova Kabinetu Ministriv Ukrainy vid 06.03.2019 r. № 167 'Pro provedennia eksperymentu z prysudzhennia stupenia doktora filosofii' [Resolution of the Cabinet of Ministers of Ukraine of March 6, 2019 № 167 'On conducting an experiment to award the degree of Doctor of Philosophy']. Retrieved from https://rada.kpi.ua/node/1020 [in Ukrainian]. 
5. Postanova Kabinetu Ministriv Ukrainy vid 21.10.2020 r. № 979 'Pro vnesennia zmin do postanov Kabinetu Ministriv Ukrainy vid 27.07.2016 r. № 567 i vid 06.03.2019 r. № 167' [Resolution of the Cabinet of Ministers of Ukraine dated 21.10.2020 № 979 'On amendments to the resolutions of the Cabinet of Ministers of Ukraine dated 27.07.2016 № 567 and dated 06.03.2019 № 167’]. Retrieved from https://www.kmu.gov.ua/npas/pro-vnesennya-zmin-dopostanov-kabinetu-ministriv-ukrayini-vid-27-lipnya-2016-r-567-i-vid-6bereznya-2019-r-167-i211020-979 [in Ukrainian].

6. Ofitsiinyi sait 'Naukova biblioteka DZ 'Dniprovska medychna akademiia MOZ Ukrainy'. Mizhnarodni naukometrychni bazy danykh. [Official site of the Scientific Library of the Dnipro Medical Academy of the Ministry of Health of Ukraine. International scientometric databases]. Retrieved from http://library.dsma.dp. ua/images/Naukovcam/Mijnarnaukbazdan.pdf [in Ukrainian].

7. Ofitsiinyi sait 'Natsionalna biblioteka Ukrainy imeni V. I. Vernadskoho'. Mizhnarodni naukometrychni bazy. [Official site of the Vernadsky National Library of Ukraine. International scientometric bases]. Retrieved from http://www.nbuv.gov.ua/node/1367 [in Ukrainian].

8. Ofitsiinyi sait 'Skhidnoievropeiskyi natsionalnyi universytet imeni Lesi Ukrainky'. Mizhnarodni naukometrychni bazy. [Official site of Lesya Ukrainka Eastern European National University. International scientometric bases]. Retrieved from https://eenu.edu.ua/uk/mizhnarodni-naukometrichni-bazi [in Ukrainian].

9. Ofitsiinyi sait 'Natsionalna biblioteka Ukrainy imeni V. I. Vernadskoho'. Nauk-metrychni bazy danykh. [Official site of the Vernadsky National Library of Ukraine. Scientometric databases]. Retrieved from http://www.nbuv.gov.ua/ node/1367 [in Ukrainian].

10. Ofitsiinyi sait 'Vikipediia. Vilna entsyklopediia'. Scopus. [Official Site 'Wikipedia. Free encyclopedia'. Scopus]. Retrieved from https://uk.wikipedia. org/wiki/Scopus [in Ukrainian].

11. Ofitsiinyi sait 'Publikatsiya nauchnykh statey'. Publykatsyia v Web of Science. [Official site 'Publication of scientific articles'. Publishing to Web of Science]. Retrieved from https://wos-scopus.com/publikacija-v-web-of-science/ [in Russian].

12. Ofitsiinyi sait 'Vikipediia. Vilna entsyklopediia'. Web of Science. [Official site 'Vikipediya. Vilna Encyclopedia'. Web of Science]. Retrieved from https:// uk.wikipedia.org/wiki/Web of Science [in Ukrainian].

13. Ofitsiinyi sait 'Vikipediia. Vilna entsyklopediia'. Google Schoolar. [Official site 'Vikipediya. Vilna encyclopedia'. Google Scholar]. Retrieved from https://uk.wikipedia.org/wiki/Google Scholar [in Ukrainian].

14. Ofitsiinyi sait 'Nauchnaya biblioteka Chernigovskogo natsional'nogo tekhnologicheskogo universiteta'. Naukometricheskie bazy dannykh. [Official site of the 'Scientific Library of the Chernihiv National Technological University'. Scientometric databases]. Retrieved from http://library2.stu.cn.ua/ru/ru/ v_pomoschj_uchenomu/naukometricheskie_bazi_dannih/[in Russian].

15. Ofitsiinyi sait 'Vikipediia. Vilna entsyklopediia'. IndexCopernicus. [Official site 'Wikipedia. Free Encyclopedia'. IndexCopernicus]. Retrieved from https:// uk.wikipedia.org/wiki/Index_Copernicus [in Ukrainian].

16. Ofitsiinyi sait 'Vikipediia. Vilna entsyklopediia'. CrossRef. [Official site 'Wikipedia. Free Encyclopedia'. CrossRef]. Retrieved from https://uk.wikipedia. org/wiki/CrossRef [in Ukrainian]. 
17. Havenko, S. \& Konyukhov, O. \& Konyukhova, I. (2019). Electronic and microscopic analysis of offset imprints of barcodes on cardboards. Journal of Graphic Engineering and Design, Vol. 10, Issue 1, 19-24 [in English].

18. Havenko, S. \& Kochubei, V. \& Labetska, M. \& Kibirkštis, E. \& Venytė, I. (2015). Thermal analysis of braille formed by using screen printing and inks with thermo powder. Medziagotyra, Vol. 21, Issue 1, 52-56. DOI 10.5755/j01. ms.21.1.5702 [in English].

19. Childs, T.H.C. \& Henson, B. (2007). Human tactile perception of screenprinted surfaces: Self-report and contact mechanics experiments. Proceedings of the Institution of Mechanical Engineers, Part J: Journal of Engineering Tribology, Vol. 221, Issue 3, 427-441. DOI 10.1243/13506501JET217 [in English].

20. Havenko, S. \& Bogorosh, A. \& Martynyuk, M. \& Kibirkštis, E. \& Vaitasius, K. (2008). Influence of technological factors on physical and mechanical properties of laminated prints. Strojniski Vestnik. Journal of Mechanical Engineering, Vol. 54, Issue 3, 225-231 [in English].

21. Imani, M. \& Ghasemian, A. \& Dehghani-Firouzabadi, M. R. \& Afra, E. \& Gane, P. A. C. \& Rojas, O. J. (2019). Nano-lignocellulose from recycled fibres in coatings from aqueous and ethanolic media: Effect of residual lignin on wetting and offset printing quality. Nordic Pulp and Paper Research Journal, Vol. 34, Issue 2, 200-210 [in English].

22. Mesic, B. \& Lestelius, M. \& Engström, G. \& Edholm, B. (2005). Printability of PE-coated paperboard with water-borne flexography: Effects of corona treatment and surfactants addition. Pulp and Paper Canada, Vol. 106, Issue 11, 36-41 [in English].

23. Tåg, C.-M. \& Toiviainen, M. \& Juuti, M. \& Gane, P. A. C. (2010). Dynamic analysis of temporal moisture profiles in heatset printing studied with nearinfrared spectroscopy. Measurement Science and Technology, Vol. 21, Issue 10. DOI 10.1088/0957-0233/21/10/105602 [in English].

24. Erkkilä, A.-L. \& Leppänen, T. \& Hämäläinen, J. (2013). Empirical plasticity models applied for paper sheets having different anisotropy and dry solids content levels. International Journal of Solids and Structures, Vol. 50, Issue 14-15, 2151-2179. DOI 10.1016/j.ijsolstr.2013.03.004 [in English].

25. Castro, J. \& Ostoja-Starzewski, M. (2003). Elasto-plasticity of paper. International Journal of Plasticity, Vol. 19, Issue 12, 2083-2098 [in English].

26. Havenko, S. \& Kibirkštis, E. \& Gegeckienè, L. \& Khadzhynova, S. \& Kadyliak, M. (2019). Influence of structure and physical-mechanical characteristics of threads on the strength of binding the books. Mechanika, Vol. 25, Issue 4, 313-319. DOI 10.5755/j01.mech.25.4.22774 [in English].

27. Kyrychok, T. \& Klymenko, T. \& Talimonova, N. \& Svezhentsova, K. (2019). Determining special features in the topography of paper with water marks at the micro- and nanolevels. Eastern-European Journal of Enterprise Technologies, Vol. 2, Issue 12-98, 28-35. DOI 10.15587/1729-4061.2019.164071 [in English].

28. Kyrychok, T. \& Shevchuk, A. \& Nesterenko, V. \& Kyrychok, P. (2014). Banknote paper deterioration factors: Circulation simulator method. BioResources, Vol. 9, Issue 1, 710-724 [in English].

29. Kao, G. Y. \& Chiang, X.-Z. \& Foulsham, T. (2019). Reading behavior and the effect of embedded selfies in role-playing picture e-books: An eye-tracking investigation. Computers and Education, Vol. 136, 99-112. DOI 10.1016/j. compedu.2019.03.010 v [in English]. 


\section{ПЕДАГОГІКА ПРОФЕСІЙНОЇ̈ ОСВІТИ}

30. Hrabovskyi, Y. \& Fedorchenko, V. (2019). Development of the optimization model of the interface of multimedia edition. EUREKA, Physics and Engineering. Retrieved from https://doi.org/10.21303/2461-4262.2019.00902 [in English].

31. Kucirkova, N. (2019). Children's Reading With Digital Books: Past Moving Quickly to the Future. Child Development Perspectives, Vol. 13, Issue 4, 208-214. DOI10.1111/cdep.12339 [in English].

32. Yoo, H.-S. \& Kim, S.-W. (2016). ESOTAG: E-book evolution using collaborative social tagging by readers. Multimedia Tools and Applications, Vol. 75, Issue 20, 12795-12813. DOI10.1007/s11042-016-3404-4 [in English].

33. Choi, J.-R. \& Hwang, J. \& Lim, S.-B. (2015). Design of User Feedback Interface for Dynamic Updating of E-Book Content. International Journal of Multimedia and Ubiquitous Engineering, Vol. 10, No. 11, 359-368 [in English].

34. Petrovic, S. \& Kasikovic, N. Sleeve type influence on flexographic print quality. Retrieved from https://www.webofscience.com/wos/woscc/fullrecord/WOS:000460950700006 [in English].

35. Kim, K. M. \& Lee, J. Y. \& Jo, H. M. Cellulose Nanofibril Grades' Effect on the Strength and Drainability of Security Paper. Retrieved from https://www. webofscience.com/wos/woscc/full-record/WOS:000493997400056 [in English].

36. Derkacheva, O. Yu. \& Tsypkin, D. O. Lignin Content in Paper Fibers Assessed Using IR Reflectance Spectroscopy. Retrieved from https://www. webofscience.com/wos/woscc/full-record/WOS:000423710700022 [in English].

37. Bondarenko, A. V. \& Gudkov, A. V. \& Shendrik, A. V. Device for measuring print quality characteristics for optically recognizable characters. Retrieved from https://www.webofscience.com/wos/woscc/full-record/WOS:000258192400011 [in English].

38. Mizyuk, O. \& Kibirkstis, E. \& Petraitiene, S. Investigation of tension of flock printing materials. Retrieved from https://mechanika.ktu.It/index.php/ Mech/article/view/12159 [in English].

39. Kibirkstis, E. \& Miliunas, V. \& Havenko, S. \& Ragulskis, K. \& Ragulskis, L. Measurement of longitudinal vibrations of the rollers in a folding machine. Retrieved from https://www.jvejournals.com/article/18375 [in English].

40. Cigula, T. \& Tomasegovic, T. \& Hudika, T. Effect of the paper surface properties on the ink transfer parameters in offset. Retrieved from https://www. webofscience.com/wos/woscc/full-record/WOS:000497995600015 [in English].

41. Kibirkstis, E. \& Augutis, S. V. \& Vainilavicius, D. Effect of dynamic regime of rollers of pocket folding machine to quality of printing products. Retrieved from https://www.webofscience.com/wos/woscc/full-record/WOS:000362551100011 [in English].

42. Yoo, S. \& Hsieh, J. S. \& Zou, P. Utilization of calcium carbonate particles from eggshell waste as coating pigments for ink-jet printing paper. Retrieved from https://www.webofscience.com/wos/woscc/full-record/wOS:000270147700039 [in English].

43. Zechner, J. \& Janko, M. \& Kolednik, O. Determining the fracture resistance of thin sheet fiber composites - Paper as a model material. Retrieved from https://www.researchgate.net/publication/257100518 Determining the fracture_resistance_of_thin_sheet_fiber_composites_-_Paper_as_a_model_ material [in English]. 
44. Wang, Z.-W. \& Gao, S. \& Hu, C.-Y. \& Wu, Y.-M. Modelling of Migration from Printing Inks on Paper Packaging. Retrieved from https://www.semanticscholar.org/paper/Modelling-of-Migration-from-Printing-Inks-on-Paper-WangGao/b7d268e59335dd313d69b44e6f17b98d7f657d40 [in English].

45. Kulachenko, A. \& Gradin, P. \& Uesaka, T. Basic mechanisms of fluting formation and retention in paper. Retrieved from https://www.diva-portal.org/ smash/get/diva2:227104/FULLTEXT01.pdfFibre [in English].

46. Havenko, S. \& Bogorosh, A. \& Martynyuk, M. Influence of technological factors on physical and mechanical properties of laminated prints. Retrieved from https://www.webofscience.com/wos/woscc/full-record/WOS:000256504600008 [in English].

47. Sousa, S. \& de Sousa, A. M. \& Reis, B. Influence of Binders on Inkjet Print Quality. Retrieved from https://www.webofscience.com/wos/woscc/fullrecord/WOS:000334672000010 [in English].

48. Korat, O. \& Falk, Y. Ten years after: Revisiting the question of e-book quality as early language and literacy support. Retrieved from https://journals. sagepub.com/doi/abs/10.1177/1468798417712105 [in English].

49. Franco, J. \& Provencher, B. A. Using a Multitouch Book to Enhance the Student Experience in Organic Chemistry. Retrieved from https://dialnet.unirioja.es/servlet/articulo?codigo=6846738 [in English].

50. Wang, J. \& Wang, L. Animation Development in Multimedia Teaching Software Based on Multimedia Tool Book. Retrieved from https://jestp.com/ index.php/estp/article/view/252 [in English].

51. Yoo, H.-S. \& Kim, S.-W. ESOTAG: E-book evolution using collaborative social tagging by readers. Retrieved from https://www.semanticscholar.org /paper/ESOTAG\%3A-E-book-evolution-using-collaborative-social-Yoo$\mathrm{Kim} / 888 \mathrm{c} 21 \mathrm{~d} 415 \mathrm{f} 27837 \mathrm{fbbec174d30e7517f441a2a3}$ [in English].

52. Osnovni vymohy do statei, shcho publikuiut $v$ zhurnalakh, yaki indeksuiutsia $v$ Scopus. [Basic requirements for articles published in journals indexed in Scopus]. Retrieved from http://ua.publ.science/uk/blog/osnovnyye-trebovaniya-k-statyam-scopus-kak-podgotovit-nauchnuyu-rabotu-kotoraya-proydet-retsenzirovaniye [in Ukrainian].

53. Yak opublikuvaty naukovu stattiu $v$ Scopus. [How to publish a scientific article in Scopus]. Retrieved from http://osvita.ua/vnz/69911/\#: :text=\% D0\%92\%D1\%96\%D0\%B4\%D1\%85\%D0\%B8\%D0\%BB\%D0\%B8\%D1\%82\%D 0\%B8\%20\%D1\%81\%D1\%82\%D0\%B0\%D1\%82\%D1\%82\%D1\%8E\%20\%D0\% B7\%D0\%B0\%20\%D1\%86\%D0\%B8\%D0\%BC\%20\%D0\%BA\%D1\%80\%D0\%B 8\%D1\%82\%D0\%B5\%D1\%80\%D1\%96\%D1\%94\%D0\%BC,\%2C\%20\%D0\%BA \%D0\%BB\%D1\%8E\%D1\%87\%D0\%BE\%D0\%B2\%D1\%96\%20\%D1\%81\%D0\% BB\%D0\%BE\%D0\%B2\%D0\%B0\%2C\%20\%D0\%BE\%D1\%81\%D0\%BD\%D0\%B E\%D0\%B2\%D0\%BD\%D0\%B8\%D0\%B9\%20\%D1\%82\%D0\%B5\%D0\%BA\%D1 \%81\%D1\%82\%2C [in Ukrainian].

54. 35 porad, yaki dopomozhut pidhotuvaty stattiu dlia publikatsii v zhurnalakh, shcho indeksuiutsia $v$ Scopus ta Web of Science. [35 tips to help prepare an article for publication in journals indexed in Scopus and Web of Science]. Retrieved from https://nim.media/articles/35-porad-yaki-dopomozhut-pidgotuvati-stattyu-dlya-publikatsiyi-v-zhurnalakh-shcho-indeksuyutsya-v-scopus-ta-web-of-science [in Ukrainian]. 
55. Kak opublikovat' stat'yu v Scopus? [How do I publish my article in Scopus?]. Retrieved from https://openscience.in.ua/scopus-article.html [in Russian].

56. Ofitsiinyi sait 'Skhidno-levropeiskyi zhurnal peredovykh tekhnolohii'. Nasha istoriia. [Official site of the Eastern European Journal of Advanced Technologies. Our story]. Retrieved from http://jet.com.ua/uk/ [in Ukrainian].

57. Ofitsiinyi sait 'Kvalilohiia knyhy'. Kvalilohiia knyhy. [Official site 'Book Qualification'. Qualification book]. Retrieved from https://www.uad.Iviv.ua/ kvalilohiia-knyhy [in Ukrainian].

58. Ofitsiinyi sait 'Naukovi zapysky'. Naukovi zapysky. [Official site 'Scientific Notes'. Proceedings]. Retrieved from http://www.uad.lviv.ua/naukovi-zapiski [in Ukrainian].

59. Ofitsiinyi sait 'Polihrafiia $i$ vydavnycha sprava'. Polihrafiia $i$ vydavnycha sprava. [Official site 'Printing and Publishing'. Printing and publishing]. Retrieved from https://www.uad.lviv.ua/polihrafiia-i-vydavnycha-sprava [in Ukrainian].

60. Ofitsiinyi sait 'Tekhnolohiia i tekhnika drukarstva'. Pro zhurnal. [Official site 'Technology and technique of printing'. About the magazine]. Retrieved from http://ttdruk.vpi.kpi.ua/ [in Ukrainian].

61. Ofitsiinyi sait 'PAN BIBLIOTEKAR'. Katehorii $A, B, V$ dlia naukovykh fakhovykh vydan Ukrainy. [Official site of 'PAN LIBRARIAN'. Categories $A, B, C$ for scientific professional publications of Ukraine]. Retrieved from https://www. xn-80abaqzevto0rc.xn_j1amh/2017/05/blog-post_17.html [in Ukrainian].

The professional editions included in the Ukrainian and foreign databases in terms of their compliance with the subject area of the specialty 186 Publishing and Printing are analyzed. International scientific metrics, such as Web of Science and Scopus, were used for analysis. The list of scientific editions for publishing researches of scientists of a specialty 186 Publishing and Printing is defined. The requirements for publishing the results of the dissertation for the degrees of Candidate of Sciences, Doctor of Sciences and Doctor of Philosophy are given.

Keywords: subject area of specialty; international scientific bases; publishing and printing; publications; scientific journals. 